\title{
CONTENDING IDENTITY IN THE ISLAMIC RITUAL: The Slametan among Surinamese Javanese Muslims in The Netherlands
}

\section{Moh Khusen}

Lecturer at the Faculty of Syariah of STAIN Salatiga

الملخص

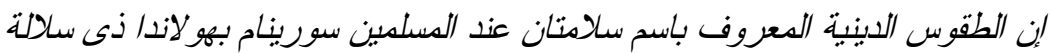

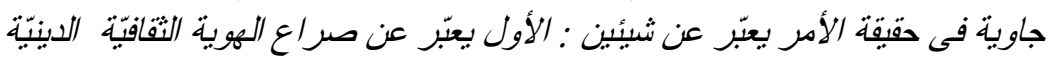

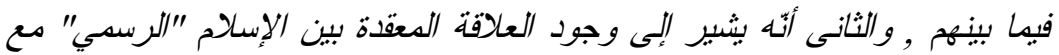

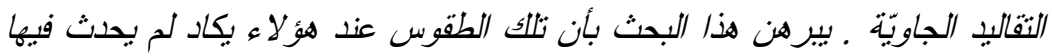

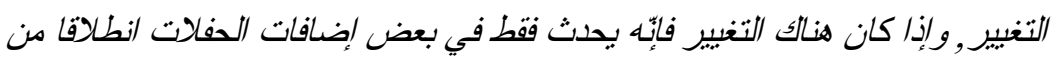

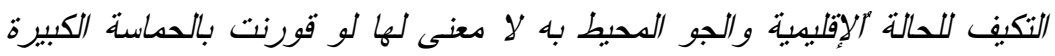

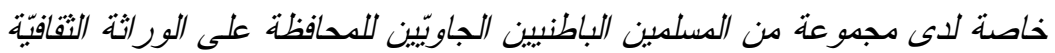

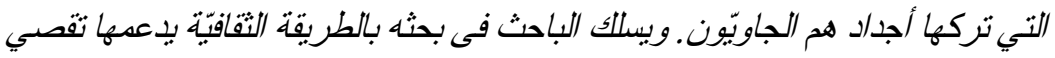

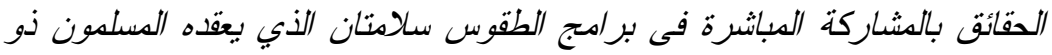

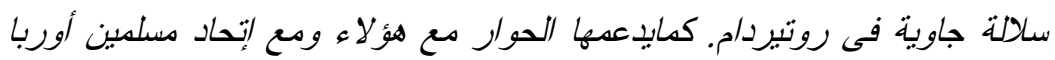

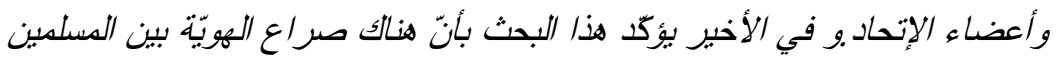

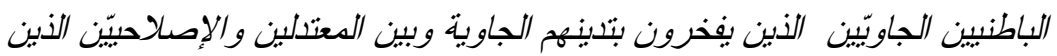

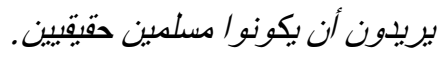

\section{Abstrak}

Wacana tentang slametan dalam masyarakat Muslim Surinam keturunan Jawa di Belanda sesunggubnya, di satu sisi, merepresentasikean sebuah pertarungan identitas kultural keagamaan di antara mereka dan, 
di sisi lain, menunjukkan sebuah bubungan yang kompleks antara Islam 'resmi' dengan tradisi Jawa. Tulisan ini membuktikan bahwa praktek. slametan dalam masyarakat Muslim Surinam keturunan Jawa di Belanda ternyata hampir tidak mengalami perubahan. Perubaban yang ada hanya berkaitan dengan aksesoris upacara sebagai akibat dari penyesuaian terhadap kondisi geografis dan iklim setempat. Hal ini tidak ada artinya dibandingkan dengan antusiasme yang sangat besar khususnya bagi kelompok masyarakat Muslim Kejawen- untuk melestarikan semua warisan budaya dari pendabulu mereka yang adalab orang Jawa. Tulisan ini pada akhirnya menunjukkan adanya pertarungan identitas antara kelompok. Muslim Kejawen yang bangga dengan "agama jawa"-nya dan kelompok moderat dan reformis yang ingin menjadi Muslim yang sebenarnya.

Keywords: slametan, bid'a, sajen, ujub, kejawen.

\section{A. Introduction}

This paper deals with an observance of the Javanese who migrated to the Netherlands via Surinam. ${ }^{1}$ Its main focus is the slametan ritual among the Surinamese Javanese Muslims since it represents an everlasting social and religious discussion symbolizing power relations and domination within the community, both in their country of origin and in the Netherlands. That is because, as Clifford Geertz emphasizes, the slametan is the most quintessential ritual in Javanese religion intended to strengthen social solidarity among its followers. ${ }^{2}$

Geertz describes the slametan as "the Javanese version of what is perhaps the world's most common religious ritual the communal feast, and as almost everywhere, it symbolizes the mystic and social

${ }^{1}$ Approximately 50.000 of the 299.700 Surinamese living in the Netherlands are Muslims; see Nathal M. Dessing, Rituals of Birth, Circumcision, Marriage, and Death among Muslims in the Netherlands, Peeters, 2001. These people are scattered in various cities though concentrated in The Hague, Amsterdam, Den Bosch, and Rotterdam. This research focuses mainly on those people living in Rotterdam.

${ }^{2}$ Clifford Geertz, The Religion of Java (London: The Free Press of Glencoe, 1960), p. 11. 
unity of those participating in it." ${ }^{3}$ In his eyes, it is a kind of a stereotypical animistic rite. Thus, there are two inherent aspects embodied in the slametan: they are the embodiment of a spiritual idea and social integration, which complement each other. Taking a different approach to Geertz, Woodward defines the slametan as "a ritual meal at which Arabic prayers are recited and food is offered to the Prophet Muhammad, saints, and ancestors, who are implored to shower blessings on the community." "The key elements in the slametan thus are the Arabic prayers and food offerings dedicated spiritually to the 'Muslim' subjects. From this definition Woodward considers the slametan to be Islamic since it has its roots in the Sufi interpretation of the tradition of Islam. ${ }^{5}$ This is why he does not hesitate to criticize Geertz's identification of the slametan as part of "animistic-Hindu" as misleading. ${ }^{6}$

The slametan then is intended to create "a state of well being, security and freedom from hindrances of both a practical and spiritual kind." This purpose can be understood in the light of the Javanese concept of slamet (being safe), which is mostly defined by scholars as the idea of slamet in a psychological and spiritual sense. Geertz, for instance, refers to it as "bodily and mental equanimity". ${ }^{8}$ In an almost similar expression, Woodward refers the idea of slamet within its social and psychological dimensions as both mental and social conditions.

${ }^{3}$ Ibid., p. 12.

${ }^{4}$ Mark R. Woodward, "The Slametan: Textual Knowledge and Ritual Performance in Central Javanese Islam," in History of Religion, vol. 28, p. 54.

${ }^{5}$ Ibid.

${ }^{6}$ The different emphasis in these definitions is, according to Masdar Helmy, mainly caused by the different character of places where Geertz and Woodward did their research. Geertz, on the one hand, did research in the small city of Modjokuto, in which nominal Muslims' views are prevalent. On the other hand Woodward did his in Central Java, where more orthodox Muslims (santri) lived. Helmy, Islam and Javanese Acculturation: Textual and Contextual Analysis of the Slametan Ritual, MA Thesis in Islamic Studies, (Montreal: McGill University, 1999), p. 45.

${ }^{7}$ Andrew Beatty, "Adam and Eve and Vishnu: Syncretism in the Javanese Slametan," in The Journal of the Royal Anthropological Institute, vol. 2, No. 2. June 1996, p. 274.

${ }^{8}$ Clifford Geertz, The Religion, p. 13.

${ }^{9}$ Woodward, “The Slametan”, p. 67. 
The individual is considered slamet when his mind is at rest, untroubled by worldly concerns or supernatural fears. While the community is slamet "when there is an adequate level of material together with an absence of social or political conflict." 10

Similar to that of which has flared up about qiblat, ${ }^{11}$ the controversy on the slametan was already causing dissensions when the Javanese Muslims still lived in Surinam. Van Wengen mentions that it began in 1930s when later immigrants form Java, who had had a frequent contact with the Muhammadiyah (an Indonesian reformist Muslim organization) conducted a campaign aimed at the purification of Islamic teachings from all foreign elements. Besides the issue of qiblat, which then divided the Javanese into two groups: wong madep ngilen (West-qiblat people) and wong madhep ngetan (East-qiblat people), those intent purification also attacked the slametan. This controversy sharpened considerably around 1950, indicated by the refusal of each the groups to attend each other's slametans and marriages formerly arranged between members of families from different group ended in divorce. ${ }^{12}$

The discourse on the slametan among Surinamese-Javanese Muslims represents a religious cultural identity and complex relationship between "official" Islam and Javanese tradition. Some of them preserve the slametan as part of their life just as their ancestors did, while some have abandoned it since they discovered that it is not part of Islamic teachings. Both have established their own position on interpreting Islam and Javanese tradition, which has been crystallized in their religious cultural identity.

As far as I know the latest work on rituals among Muslims in the Netherlands is written by Nathal M. Dessing. It bears the title Rituals of Birth, Circumcision, Marriage, and Death among Muslims in the Netherlands. In this work, Dessing gives a quite detailed account and comparative

${ }^{10}$ Ibid., p. 67.

${ }^{11}$ The beautiful discussion on this issue can be found in Ichwan, "Continuing Discourse on Keblat: Diasporic Experiences of the Surinamese Javanese Muslims in the Netherlands", in Sharqiyyat 11 (1999), p. 101-119.

${ }^{12}$ Van Wengen, The Cultural Inheritance of the Javanese in Surinam, (Leiden: E. J. Brill, 1975), p. 7. 
analysis of the rituals held at the life crisis ceremonies among various Muslim communities in the Netherlands. This wide topic and area of study precluded any elaboration on the slametan among Surinamese Javanese Muslims. The limitation to the life cycle rituals also prevented her from elaborating on other slametans outside those to do with the life cycle, such as those associated with the Muslim ceremonial calendar.

Another work is an article written by M Nur Ichwan in the journal Sharqiyyat. ${ }^{13}$ In this article Ichwan also identifies three groups of Surinamese Javanese Muslims, which represent the different practices related the slametan: they are the Kejawen Muslims; the moderatereformists; and the reformists. However, unlike Dessing who considers that the reformist Muslims refuse to perform the slametan, ${ }^{14}$ he says both of the moderate-reformist and the reformist still perform the slametan although they change its name to kajatan or sodaqoban. ${ }^{15}$ Mainly interested in the matter qiblat, he only touches upon the slametan in a more general way and, consequently, does not comprehensively elaborate on the slametan.

This present research attempts to fill the lacuna as well as to give an answer to the conflicting accounts about the moderate-reformist and reformist position towards the slametan. However, since this research was carried out only in Rotterdam, it might not be sufficient to represent the real situation in the Netherlands unless more data from other cities are included. The questions that will be answered in this study are: how do the Surinamese Javanese Muslims perform the slametan? Why are there varying practices in the way of performing the slametan among them? And to what extent, if any, have the practices changed from those in their country of origin? Research was conducted from June 2004 to February 2005 and consisted of participant observation and interviews. As a participant observer, I attended a slametan held by a member of Al-Jami'atul Hasanah, an organization of East-qiblat people, and another held by members of Sida Mulya, an organization of West-qiblat people. Another group, Rukun Islam, has

\footnotetext{
${ }^{13}$ M. Nur Ichwan, “Continuing”, p. 101-119.

${ }^{14}$ Nathal M. Dessing, Rituals of Birth, p. 72.

${ }^{15}$ M. Nur Ichwan, "Continuing", p. 115.
} 
no such ritual meal. I interviewed leaders and some members of each group. I also interviewed Pak Naf'an Sulhan, one of leaders of PPME (Persatuan Pemuda Muslim Eropa), an Islamic organization for Indonesians that also has a close relation with Al-Jami'atul Hasanah.

This study is arranged in the following order. Part One is introduction, which explains the reason and aim of this research, followed by the method applied to it. The religious grounds of the slametan are presented in Part Two explaining the debate on the ritual in Islam. Part Three deals with the research description and findings consisting of the types of slametan and their implementation among Surinamese Javanese Muslims. The last part is a conclusion.

\section{B. The Religious Grounds of the Slametan}

The slametan is often conceived of as a result of the on-going process of Islamization conducted by the nine saints in Java. ${ }^{16}$ Consequently, clearly to be found in the slametan is a synthesis of the indigenous believe (Hinduism) and Islam. It is the most obvious case of a "syncretistic" ritual that was said to have been invented by Sunan Kalijaga, one of the most renowned saints of Java. ${ }^{17}$ As a product of ancient Javanese religious ritual but clothed with Muslim fashion, the slametan links normative Islam as an idealized reference to its social interpretation. The elements of scriptural Islam included in the slametan have been established to accommodate the local tradition, because this was thought as the best way to propagate Islam in Java. ${ }^{18}$

Therefore, Muslims who denied performing the slametan explained their decision by saying that it is not part of Islam and consider its performance heresy (bid'a) and shirk. ${ }^{19}$ To be a Muslim one should strictly

${ }^{16}$ See "Kenduri" in Harun Nasution (Ed.), Ensiklopedi Islam Indonesia IAIN Syarif Hidayatullah Jakarta, (Jakarta: Djambatan, 1992), p. 533.

${ }^{17}$ Mark R. Woodward, Islam in Java: Normative Piety and Mysticism in the Sultanate of Yogyakarta, (Tucson: The University of Arizona Press, 1989), p. 96.

${ }^{18}$ Masdar Helmy, Islam and Javanese Acculturation, p. 75.

${ }^{19}$ In the context of Indonesia this 'everlasting' debate is represented by the two major Islamic organizations: NU and Muhammadiyah. The former accepts the slametan as part of its doctrine and, the latter rejects it and attempts to eliminate the practice from the community. See Zainuddin Fananie and Atiqa Sabardila, Sumber Konflik Masyarakat Muslim Mubammadiyah-NU, (Surakarta: Muhammadiyah University Press, 2000). p. 80. 
follow the Islamic teachings written in the Qur'an and not become involved in practices connected to the worship of devils and other invisible beings. A Muslim should worship only Allah. By following the law of Allah, human beings not only are tied to each other but also under His protection. According to them, the Prophet completely thought how Muslims should perform their religious observances and, therefore, all kinds of innovations in this realm must be considered heresy and all heresies, according to them, are unlawful. ${ }^{20}$

On the other hand, Muslims who continue to perform the slametan believe that the ritual has already been Islamized which is indicated by some Islamic elements replacing those deriving from Hinduism, strongly represented by three main practices: offering sajen; burning incense; and mentioning spirits and other invisible beings in the supplication. These practices have being replaced by reciting some Qur'anic verses and a couple of Arabic prayers. As a result, it is an acceptable heresy (bid'a hasana) rather than prohibited one (bid'a sayyi'a), which rules out it being shirk. ${ }^{21}$ Referring to Ibn Taimiyya in his Iqtida al al-Sirät alMustaqim, they suggest that many good deeds conducted by Muslims were never done by the Prophet and as long as they do not transgress Islamic law, they are not considered a prohibited heresy. ${ }^{22}$ They believe that the slametan is a part of custom that has been incorporated into Islam. This tradition is legalized by a juridical principle of Islamic law, "al-'ada muhakkama," means "a tradition which is not contradictory to the shari'a can be justified as law". ${ }^{23}$ Since, then, the ritual itself is not contradictory to the Qur'an and the Hadith, it can be accepted as one of the acceptable religious services ( $i b \bar{a} d a$ ) in Islam. ${ }^{24}$

In addition to this is the "implicit" sanction given in the Qur'an and the Hadith. First of all, slamet is a religious and mystical term derived from the Arabic word salam which is also used in the Qur'an in a general sense for tranquillity in this life and in the Hereafter. In the
${ }^{20}$ Ibid., p. 107.
${ }^{21}$ Ibid., p. 98.
${ }^{22}$ Ibid., p. 99.
${ }^{23}$ Annemarie Schimmel, Mystical Dimension of Islam, (Chapel Hill: The University pf North Carolina Press, 1975), p. 187.
${ }^{24}$ Masdar Helmy, Islam and Javanese Acculturation, p. 86. 
context of religious traditions, salam is also used as a salutation for humans, spiritual beings, saints, and angels. ${ }^{25}$ The phrase "al-salam 'alaykum" (peace be upon you) is an obvious use of the word salam in Islam as a request for a blessing from Allah for the person addressed in either a ritual or a social context. The persons to whom the phrase is addressed are obliged to reply by saying "wa 'alaykum al-salam wa rabmat Allăh wa barakētub" (On you be the peace, blessing and mercy from Allah). ${ }^{26}$

In Islamic texts and religious discourse, salam is added after mentioning the name of a prophet and frequently in the case of angels, saints, and other esteemed religious figures. The Prophet Muhammad is also said to have used the salam as a salutation for the previous prophets, for martyrs and other deceased Muslims. ${ }^{27}$ Among the stories about the Prophets' salutations, a hadith concerning his salutation to the dead has become a source of Islamic eschatology, which stimulates particular customs such as visiting graves and offering prayers for the dead. ${ }^{28}$

The second key concept to understand the essence of the slametan is through the idea of charity (sadaqa) as a kind of 'ibada which is also strongly recommended by the Qur'an and Hadith. Since the definition of charity is very broad, it includes all benevolent actions such as the

${ }^{25}$ These salutations are derived from Sürat al-Nür: 61, al-Nisà': 86, and al-An'àm: 54. Woodward, “The Slametan”, p. 67.

${ }^{26}$ Besides being motivated by the above-mentioned verse (al-Nisä': 86), this complete way of replying the salam is recommended by two hadiths. The most significant is: "Barā'a ibn 'Āzib relates: The Holy Prophet enjoined the following seven on us: visiting the sick, following a funeral, calling down the mercy of Allah on one who sneezes, supporting the weak, helping the oppressed, multiplying the greeting of peace, and fulfilling vows." Another one is "Abdullāh ibn Salām relates that he heard the holy Prophet say: O ye people, multiply the greeting of peace, feed people, strengthen ties of kinship and be in prayer when others are sleep, you will enter paradise in peace." Ibid., p. 68.

${ }^{27}$ C. van Arendock. "Salam", in The Shorter Encycloopaedia of Islam, ed. H. A. R. Gibb and J. Kraners, (Leiden: E. J. Brill, 1953), p. 490.

${ }^{28}$ The hadîth is: "Burayda relates that the Prophet taught that any of them visiting the cemetery should say: Peace be on you dwellers of this home of believers and Muslims, and we, if Allah so wills, shall join you. I supplicate for peace for you and ourselves.” Woodward, “The Slametan”, p. 68. 
distribution of food to the poor, neighbours, and kin. It is believed that feeding the poor is a religious duty and a source of blessing both for donor and recipient. The food distributed in the slametan, consequently, has greater value than the rakat since, unlike zakatt, which is legally obliged and thus it is not a pure gift, it is a real gift originating from a deep desire to help others. ${ }^{29}$ Thus even though it is not answering obligatory injunction (wäjib), charity in Islam is meritorious.

The Islamic character of the slametan also can be found in the prayer $\left(d u^{\prime} a\right)$ recited at the end of the ritual. In Islam, $d u^{\prime} a^{\prime}$ is a prayer of supplication to ask mercy from Allah or to assure His blessing and protection. The Qur'an guarantees that Allah will respond to the requests of believers. ${ }^{30}$ Since the precise form of the $d u^{\prime a} a$ ' is not determined by the textual sources, it may be recited in Arabic as well as in other languages. As the core element of the slametan, the $d u^{\prime} a^{\prime}$ ' can be understood as the total dependency of human beings to their God. Taking the Sufi approach the concept of dependency might be described as God's supremacy over all His creatures, including human beings. Even in an extreme form of Sufism, human beings are "the slaves of God"; they have no importance before God and are nothing but an instrument of eternal fate. ${ }^{31}$

\section{Research Description and Findings}

Parsudi Suparlan classifies Surinamese Javanese Muslims into traditionalists, reformists, and moderate-reformists. The traditionalists are those who still face West in their prayers and do not strictly adhere to Islamic teachings and practices and try to preserve the continuity of Javanese culture. Opposed to them are the reformists who have changed the direction of their prayers to the East and attempt to purify Islamic teachings by reference to the Qur'an and the Prophetic traditions. In between these two groups, the moderate-reformists take the same attitude towards Islamic teachings but they still tolerate much of the Surinamese Javanese cultural systems, especially ceremonies

\footnotetext{
${ }^{29}$ Ibid., p. 64.

${ }^{30}$ See for example Sürat al-Baqara: 187, al-A'räf: 56, and al-Naml: 63.

${ }^{31}$ Annemary Schimmel, Mystical Dimension of Islam, p. 187.
} 
marking the life cycle. ${ }^{32}$

Since all those three groups are also to be found in the Netherlands, Suparlan's classification is used in this research, but with a little adjustment. Here I agree with Ichwan's using the name Kejawen Muslims rather than traditionalists for the first group, since it is the real name used in their country of origin and even they identify themselves as Kejawen. ${ }^{33}$ The two other groups are differentiated by their theological and legal bases. While the moderate-reformists look to the Ash'arite-Shafi'ite school, the reformists extend their outlook to the Hanbalite and Wahhabite schools. Furthermore, unlike when they were still in Surinam, the moderate-reformists in the Netherlands no longer tolerate the burning incense and offering sajen, ${ }^{34}$ although they do not openly criticize these practices.

The foremost characteristic of Kejawen Muslims, including members of Sida Mulya (founded in 1979), is that they have a syncretic understanding of Islam. Islam for them is intertwined with older Javanese beliefs including Hindu-Buddhist beliefs. Even though this group is also called wong madhep ngilen (West-qiblat people), indicating their direction in prayer, they actually do not have a mosque. What they have is a multi-purpose room in which all their activities take place, from having a meeting to performing slametan. Instead of being completed with prayer furniture and Islamic accoutrements such as prayer rugs, a niche for imam (mib̧rāb), a pulpit for khutba, and Arabic calligraphy, the room is decorated with a puppet of Arjuna and Srikandi, the two most favourite characters among the leather puppets (wayang kulit), ${ }^{35}$ hanging on the wall.

32 Parsudi Suparlan, The Javanese in Surinam: Ethnicity in an Ethnically Plural Society, Ph.D. thesis submitted to University of Illinois, (Urbana: University of Illinois, 1976), pp. 205-206.

${ }^{33}$ Interview with Pak Eddy Soeroikromo, the secretary of Sida Mulya, on February $11,2005$.

${ }^{34}$ Suparlan says that in the 1970 s, moderate-reformists in Surinam still performed some Javanist practices such as burning incense and offering sajen, although with some modifications. The Javanese in Surinam, p. 224.

${ }^{35}$ Arjuna is the famous Pandawa warrior who is also the essence of the Javanese concept of nobility. Indeed, the Javanese kings sought to enhance their legitimacy by claiming direct descent from Arjuna, and through him back to the Gods of Hinduism. 
Conversely, the moderate-reformists and reformists both have their own mosques in which the mibräb faces the southeast. They use the mosques for prayers (salat), giving religious instruction (pengajian), courses on Islam and discussions (mushäwara). Other non-religious activities, including slametan, are held outside the mosque. A moderatereformist organization, Al-Jami'atul Hasanah (founded in 1980), shares its office, mosque, and activities with the PPME (The Association of European Muslim Youth), in the same building as that of the Kejawen Muslims in Stichting Setasan Centrum Santosa Rotterdam. Ichwan's account is very clear describing how this cooperation has influenced the religious orientations of this group. For instance, its members like salawatan (reading șalawät) such as Șalawät Badr and Șalawät Näriya and the like, especially before performing $\$$. This practice is totally eschewed by its counterpart, the reformists, not to mention by the Kejawen Muslims. ${ }^{36}$

Another group, Rukun Islam (founded in 1980), represents a reformist organization. It has an informal relationship with the ICCN (Islamitisch Cultureel Centrum Nederland), which has links with the Muhammadiyah, the largest reformist Muslim organization in Indonesia. Some ICCN members, such as Sufjan S. Siregar and Sjukur, are the regular khätibs and Islamic teachers of Rukun Islam. Again Ichwan gives a valuable account about the history of this group. According to him, this group was founded in 1980 as the moderate-reformist organization, but in 1986 it began campaigning for a programme of "purification" under the pioneering effort of the young generation. However, under Pak Muslih Mardi's guidance, Rukun Islam was still moderate. Then, after he went back to Surinam in 1988, especially in 1990s, the programme has been intensified further. ${ }^{37}$ This account is indeed very helpful in explaining the discrepancy between Ichwan himself and Dessing about whether the reformists Muslims still hold the slametan. That Dessing's conclusion is negative is reasonable since she did her research between 1993 and 1997, while Ichwan's conclusion is positive because he relied much more on Landman's account, which

\footnotetext{
${ }^{36}$ M. Nur Ichwan, “Continuing”, p. 109.

${ }^{37}$ Ibid., pp. 109-110.
} 
was collected before $1991 .^{38}$

\section{Slametan Suran among the Kejawen Muslims (members of Sida Mulya)}

The slametan occurs very frequently in the Kejawen Muslims in comparison to its frequency in other communities. Generally, two types of slametan are performed by them: slametans arranged by individual families and slametans organized by the community. The former includes all slametans connected to the life cycle: pre-natal (mbobot); birth (babaran); circumcision (khitanan); marriage (mantenan) and death (kematian). On the other hand, the latter includes those associated with the Muslims ceremonial calendar (slametan sasi) such as Muludan to commemorate the birth of the Prophet Muhammad; Suran which is held in the month of Sura, ${ }^{39}$ Rejeban which reminds believers of the night when the Prophet ascended to heaven to meet Allah; and Ruwaban which is held just before the fast of Ramadan starts and is dedicated to the spirits of the deceased.

It is clear from my interviews that the Kejawen Muslims still remain faithful to performing these kinds of slametan, including another second type of slametan called Bersib Deso which is held to cleanse the village from evil spirits. As was mentioned in the introduction how the Kejawen Muslims perform the individual slametans has been discussed by Dessing although in a less comprehensive way. Here, I will deal with the communal slametans especially, that which is called slametan Suran which I attended in Stichting Setasan Centrum Santosa Rotterdam.

Unlike in the slametans held by individual family in which the food is provide by the host, in the communal slametans, including Slametan Suran, the food is brought by the participants themselves. This is what they called ambengan. On the evening of the ninth day of Javanese month (Sura), the participants came from all directions to the Stichting. Most of them were accompanied by their wives carrying dishes

${ }^{38} \mathrm{Ibid}$., p. 110. The refusal of the reformist Muslims to hold the slametan is also supported by Pak Naf'an Sulhan, one of leaders of PPME. Its members regard the slametan as bid' $a$ and consequently Muslims who perform it are being called ablal-bida'. Interview on February 14, 2005.

${ }^{39}$ In Islamic calendar this month parallels with Muharram. 
and pans holding the ambengan for their husbands who would attend the slametan. The time and place at which this slametan would be held had been common knowledge among them since they hold a weekly meeting in the Stichting to discuss problems of organization as well as preparing for the forthcoming slametan. ${ }^{40}$

That is to say that the presence of the females does not mean that they are taking part in the slametan ritual alongside with their husbands. Just like the individual slametans, the Slametan Suran is attended only by the male members of the group. The females gathered in another room, sitting and chatting about various things. However, as Koentjaraningrat says, that although overtly dominated by males, the women play an important role behind the scenes. Especially at individual slametans, they are the persons who decide on fixing the date of the slametan, on who is going to prepare the food, on who is to be invited and to be sent food parcels. ${ }^{41}$

In the main room, the participants, many of them but still a minority, wearing a white shirt and black velvet, ${ }^{42}$ sat on the floor with the legs crossed. They formed a circle facing the food, covered with aluminium foil, placed in the centre of the room. According to Pak Legiman, an active member of the group, they used banana leaves to cover the food when they were in Surinam, but since the banana plant is very rare in the Netherlands, they used aluminium foil to replace it. ${ }^{43}$ The food is divided into two parts: the food that is prepared to be consumed by the participants and the food prepared for spirits and other invisible beings. Hardly varying from that served at other slametans, the former, often called uba rampe, consisted at least of rice, chicken cooked in various ways, seasoned vegetables, fried rice chips, jajan

${ }^{40}$ In this regard, Van Wengen mentions that in Surinam the announcement for conducting the communal slametans was made by the village headman by giving a repeated series of beats on his kenthongan (a signal-drum made from hollow bamboo or wood). Van Wengen, The Cultural Inheritance, p. 20.

${ }^{41}$ Koentjaraningrat, Javanese Culture, (New York: Oxford University Press, 1985), p. 349 .

${ }^{42}$ Almost all of those not wearing this kind of clothing were younger members of the group.

\footnotetext{
${ }^{43}$ Interview on February 18, 2005.
} 
pasar, and boiled eggs. Meanwhile, the latter, called sajen, consisted of burning incense, a glass of water filled with some melati blossoms, ${ }^{44}$ and several plates of porridges.

The Kejawen Muslims' determination to provide sajen has much to do with their belief in the spirits and other invisible beings. According to Pak Umar, one of the kaums (religious leaders) in the group, a slametan is performed for the well being of the host, the guests or participants in the slametan, the whole community and other invisible beings. There are some spirits that they should treat with respect; these are angels, prophets, ancestors and dead relatives, and guardian spirits who ensure that universe is kept safe for humans. The spirits are just like human beings, but since they do not eat the regular food, they consume only the scent of the flowers, the aroma of the special kinds of food, and the smoke of the burning incense. Most decidedly, the offerings are not meant to worship devils or spirits, but are intended to be a sign of honour and respect. Thus mentioning the names of the angels, prophets, and other invisible beings in the slametan (ujub) followed by offering them certain kinds of food does not mean that they really eat the food, but the whole process is a symbolic way of them expressing honour and respect. ${ }^{45}$

In contrast to Suparlan's accounts that slametan is always opened by a kaum, ${ }^{46}$ the Slametan Suran was opened by the leader of the group. After expressing gratitude and showing his appreciation of all participants in the slametan, the leader explained the purpose and agenda of the evening's slametan, followed by names of persons who were responsible for conducting each of them. The slametan was began with a speech (khutba) elucidating the history of the month (Sura) and why they should perform a slametan in it. It was said that Sura is closely connected with important events in the lives of the prophets from Adam to Muhammad. For example: in this month, Adam's repentance was accepted by Allah; Yusuf was liberated from the jail; Yunus was

${ }^{44} \mathrm{It}$ is interesting to note that, according to some informants, since they are not always available especially in the winter, the melati blossoms are often replaced by the gricant which has a very similar scent.

${ }^{45}$ Interview on February 11, 2005.

${ }^{46}$ Parsudi Suparlan, The Javanese in Surinam, p. 222. 
freed from the abdomen of a fish; Ibrahim was saved from being burned, 'Isa was ascended to heaven, and so forth. It is interesting to note that there was no emphasis in the speech that the slametan was held in honour of Hasan and Husein, the grandsons of the Prophet Muhammad, a point also made by Parsudi Suparlan ${ }^{47}$ and Van Wengen. ${ }^{48}$

Then the slametan continued with the burning of incense by a kaum. Before this was performed, several participants unwrapped all the food as well as the sajen. Putting the prepared sajen in front of him, the kaum burned the incense and murmured an incantation. No participant knows what exactly he was saying, but by listening attentively I observed that one sentence he often uttered was "lā iläha illa Allāh Muhammad rasül Allāh" (there is no God but Allah, Muhammad is his messenger). When he had finished, the kaum asked one of participants to throw away the burned incense and leave the porridges in the room. ${ }^{49}$ The porridges were consumed, together with other food, by some participants directly after the slametan was finished. This is again contrary to Van Wengen's account that the sajen are "taken by children on the following day". 50

After that, the slametan proceeded to the next step with the pronouncing of the ujub (a formal and elaborated statement of intent about the purpose of the slametan which is currently being held ${ }^{51}$ by another kaum designated to do this. Like the burning incense, this is another specific character of the Kejawen Muslims' slametans. In this ujub each of the invisible beings are specifically as the recipients of special kinds of food to honour and respect them. Between the passages that the kaum was pronouncing, the participants expressed their accord by saying 'inggib' (a Javanese word for 'yes').

${ }^{47}$ Ibid., p. 219.

${ }^{48}$ Van Wengen, The Cultural Inheritance, p. 20.

${ }^{49}$ Here, Pak Legiman told me that in Surinam they put the burned incense and porridges next to the main door of the building where the slametan was being held, but in the Netherlands this has lapsed. He said that it is enough to do it in the room and, besides it is merely a symbol of protecting themselves from evil and other bad spirits from inside the building. Interview on February 18, 2005.

${ }^{50}$ Van Wengen, The Cultural Inheritance, p. 22.

${ }^{51}$ Parsudi Suparlan mentions that the Kejawen Muslims in Surinam call it ijab kabul, but my informants also call it ujub or iklar (supposed it is from Arabic 'iqrär'). 
The final phase of the slametan is the prayer in Arabic recited by another man designated to do so. Here, unlike other persons who open their speech with a Javanese greeting, sugeng dalu (good evening), he opened his speech with Arabic greeting, al-salam 'alaykum wa rahmat Allāh wa barakätuh. Then, with a palpable Javanese accent ignoring the tajwid rules for the reading Arabic, he read some Qur'anic passages preceded by the Surat al-Fätiha, followed by al-Ikhläs, al-Falaq, and al$N \bar{a}$ s. It is interesting to note here that when the participants were invited to join in reading the Sürat al-Fätiha, but they only respond to it by shouting the word "al-Fatiha" without reciting all the seven verses of the skra. This is contrary to the moderate-reformists who always recite those skrats in unison in their slametans. As in pronouncing the ujub, in this part the participants also expressed their accord in between the Arabic passages, but instead of saying 'inggib', they uttering 'amin'. The end of the Arabic prayer means the time had come to divide the various kinds of food among the participants.

\section{The Practice of Aqiqahan among Moderate-Reformists (al- Jami'atul Hasanah)}

Like the above-mentioned the moderate-reformists tried to combine Islamic teachings and elements of Javanese custom and tradition. They have changed their qiblat from the West to the East, but they still perform the slametan with some modifications. Their practice of slametan differs not only from that of the Kejawen Muslims but also from what they used to perform in Surinam. Parsudi Suparlan mentions that the moderate-reformists in Surinam still retained the practices of offering sajen and burning incense. The only different thing is the ideological basis for the interpretation of these practices. ${ }^{52}$ Conversely, the moderate-reformists united in the Al-Jami'atul Hasanah no longer practice the offering sajen and the burning incense.

${ }^{52}$ Parsudi Suparlan mentions that besides revising the ideological basis in order to accord with the Islamic teachings, the moderate-reformists also give new interpretations to the practices. For example, rather than interpret the burning incense as worshipping devils or inviting them to participate in the slametan, they intend it to clean the air with aromatic scent and to sanctify the slametan itself. Parsudi Suparlan, The Javanese in Surinam, p. 224. 
Pak Reksokarijo, a leader of Al-Jami'atul Hasanah, admits that members of the group still gather for meals, especially to commemorate events in the life cycle of a person, but the performance is different in the case of the slametan held by the Kejawen Muslims. For him "the most important thing is what one intends in one's heart and says with one's mouth". ${ }^{3}$ That is to say that the members of his group no longer intend to offer to and invite the spirits and other invisible beings when they hold the gathering. Unlike the Kejawen Muslims who generally believe that the souls of dead people can still hear, eat, and smell, the moderate-reformists consider that the souls are no longer able to do these things. This is why they have changed the term slametan in preference to Arabic names such as "kajatan", "tahlilan", and "aqiqahan", 54 although sometimes some members still use the term slametan. ${ }^{55}$

At the aqiqaban of a member of this group, which I attended, the ceremony held was simple. There was no long passage of ujub, the offering of sajen, and the burning incense. The ceremony was opened by Pak Yunus as religious leader of the group. After expressing his gratitude and showing appreciation of all participants in the slametan, he explained the purpose of the gathering. It was clear from the speech that he also pronounced what the Kejawen Muslims call ujub, but since he mentioned Allah as the only God they ask for help, the ujub is much shorter than that of the Kejawen Muslims. The ceremony was continued by reciting the Süra Yäsin in unison led by one of members of the group. ${ }^{56}$ Like the above-mentioned slametan, this aqiqaban ended with an Arabic prayer recited by another member designated to do so.

${ }^{53}$ Interview on June 14, 2004.

54 “Kajatan" usually used for a 'slametan' held preceding circumcision and marriage, "tablilan" for the death ceremony, and "aqiqaban" for the birth ceremony.

${ }^{55}$ It happened when I was invited to an aqiqahan in Pak Yunus' house. When I called on mbak Nina, one of Al-Jami'atul Hasanah members, to ask her to help me finding the house, she replied: "O, sampeyan juga diundang ning slametane Pak Yunus?" (So, you are also invited to attend Pak Yunus' slametan?).

${ }^{56}$ According to Pak Yunus, sometimes they invite one of the PPME leaders to lead the ceremony, especially to lead this Sürat Yasin reciting as well as to recite Arabic prayer. Interview on July 24, 2004. 
After that, the participants joined in a shared meal provided by the host. They consumed all of the meal in the house and, unlike in the slametan, there is no berkat (portion of the food brought home by the participants) for the aqiqahan. The meal was also much more simple than that in the slametan. Unlike during the phase of the aqiqahan ceremony which is dominated by male members, the female members of the group came into the room and joined in consuming the meal, chatting, and watching a film. One part of this aqiqaban ceremony is the shaving of the baby's hair and giving it a good name. As Dessing says, usually this ceremony is held when the baby is eight lapan days old. ${ }^{57}$

Similarly to the moderate-reformists, the reformists Muslims united in Rukun Islam also reject the offering of sajen, the burning of incense, and other animistic practices still espoused by the Kejawen Muslims. However they are more intolerant about any broaches of Islamic teachings than the moderate-reformists. They completely disagree with the slametan ceremony even though it has been modified and supplemented by Islamic elements. In their eyes, the modified slametan is still syncretized with the Javanese beliefs, especially in the belief that human beings need commemoration ceremonies in their life cycle.

According to one of the leaders of Rukun Islam, the slametan has more to do with the animist practices that non-Muslim and nominal Muslims considered important, such belief in spirits and superstitions regarding lucky and unlucky days and numbers. ${ }^{58}$ Besides that, "it was never performed by the Prophet, his Companions, his Followers, and

${ }^{57}$ In her book, Dessing has misleadingly written that it is performed in the eighth lapan month after birth. In Javanese calendar, one lapan (selapan) is thirty-five days. Thus the addition of the word "month" after "lapan" has made the sentence unclear. Dessing, Rituals of Birth, p. 35.

${ }^{58}$ In this regard, Parsudi Suparlan mentions that the Kejawen Muslims believe that there are good, fair, and bad months. While the good and bad months are permanent by nature, the fair months are bad months that can be changed into good ones through certain ritual acts. The good ones are Jumadil Akir, Rejeb, Ruwah, and Besar. The fair ones are Sapar, Rabingul Akir, Jumadil Awal, and Sawal. The bad ones are Sura, Mulud, Pasa, and Dulkangidah. Parsudi Suparlan, The Javanese in Surinam, p. 256. 
even by his Followers of the Followers". ${ }^{59}$ From an economic perspective, a member of this group added that performing a slametan is contradictory to Islamic teachings that stress the importance of saving money. The money should be invested in trade and business activities, and other more valuable pursuits not only for consumption or pleasure. ${ }^{60}$

\section{Islam and Agama Jawa (Javanese Religion)}

In my interviews and exchange of ideas with some the Kejawen Muslims, they often referred to their religion as Agama Djawa (Javanese religion). Even though in fragmented accounts, they told me that one of its characteristics is the concept of manunggaling kawulo lan gusti (the unification of humans being and God). The gusti is interpreted as the soul of the individual human being, and the kawulo is their whole body. If the soul is able to conserve more good power in and exclude all evil powers from the body, the state of manunggaling kawulo lan gusti is attained. ${ }^{61}$

This concept is very important to the Kejawen Muslims, even more important than the conducting religious devotions ('iba da $\bar{a} t$ ) required by the Shari' $a$ such as the salat and hajj. ${ }^{2}$ Just as Woodward says that in its totality slametan represents the use of esoteric Sufi concepts as a social and religious ideal. ${ }^{63}$ While the moderate-reformists consider the slametan a supplementary source of blessing, for them the reverse is true; the slametan is essential, and Shari' $a$ teachings are supplementary. ${ }^{64}$ They believe that the most important thing for a human being is purifying both heart and tongue (refraining from hurting and offending others). If a person can successfully conduct such purification, all the devotions are regarded as nothing compared to this achievement. That is why most of the Kejawen Muslims do not

\footnotetext{
${ }^{59}$ Interview on February 11, 2005.

${ }^{60}$ Interview on February 11, 2005.

${ }^{61}$ Parsudi Suparlan, The Javanese in Surinam, pp. 293-294.

${ }^{62}$ James L. Peacock, Purifying the Faith: The Mubammadijah Movement in Indonesian Islam, Arizona: Arizona State University, 1978, p. 16.

${ }^{63}$ Woodward, “The Slametan”, p. 83.

${ }^{64}$ Ibid., p. 82.
} 
perform Islamic religious devotions. ${ }^{65}$

Besides adopting this stance, they are critical of those who pray five times a day every day but while they are praying their minds are thinking about kadonyan (the worldly material things), lust, and not really concentrating on the God they are praying to. To them, these persons are not really praying, but just njengkang-njengking (squatting down and standing up) and are just trying to impress other people by appearing to be devout. For this reason, the Kejawen Muslims are afraid of being considered liars by God, by other people and by themselves. ${ }^{66}$

Performing the slametan and offering the sajen also represent another basis of the Agama Djawa, namely the concept of sacrifice. Implicit in this concept is the lesson of gift and reciprocity. If a person gives some of his belongings to the universe, he will receive what he has intended in his supplication (ujub) and prayer (donga). Here, the Kejawen Muslims consider that Agama Djawa and Islam share a basic similarity since both serve to bring peace, happiness, and well-beings to all human beings. The ujub and the donga have the same meaning; the only difference is that the former is in Arabic and the latter is in Javanese. ${ }^{67}$

In contradiction to this, the moderate-reformists and the reformists emphasize the importance of performing religious devotions ('ibādat) since they are pillars of Islam. Performing them is part and parcel of being a real Muslim. It is true to say that performing the 'ibädàt is not a guarantee that one will be a good person, but it is a path which has to be followed. They argued that, the Kejawen Muslims do not really know about Islam and Javanese culture; what they do is just to continue traditions and practices inherited from their ancestors in Java. In this regard, I was struck by the fact that no one of three key persons in Sida Mulya (Pak Umar, Pak Senen, and Pak Legiman) even knows the name of the leather puppets hanging on the wall of the

${ }^{65}$ According to Pak Eddy Soeroikromo, another reason is that it is very difficult for them to pray five times a day in the Netherlands because it is difficult to find mosques or places for praying and, because of full day working, they have no time left. Interview on February 11, 2005.

${ }^{66}$ Interview on June 14, 2004.

${ }^{67}$ Interview on February 11, 2005. 
room. To hide from their ignorance, they replied my question with another question why as a Javanese I did not know either.

This kind of ignorance is also clear from their conception that Islam has only to do with Arab people, and since their ancestors have already established for them the Javanese religion, they do not need to abandon it and embrace that of Arabs. Therefore, they have been doing everything they can to maintain their heritage even though this leads to make large financial sacrifices. Pak Eddy Soeroikromo told me that in order to make a pair of kembar mayang (coconut fronds shaped into ornaments for wedding or other feasts) they have to 'import' young coconut leaves from Java. ${ }^{68}$

Ichwan says that, because of these dissimilarities, the slametan is usually held by members of each group separately, not between or among the groups. If the Kejawen Muslims hold a slametan, they do not invite the other groups and vice versa. During my observation, I consistently received the answer that the slametan is still becomes a sensitive issue among them. According Pak Umar (Sida Mulya) and Johnny Kasio (Al-Jama'atul Hasanah), the slametan treading on thin ice. It has really happened that because of this, they used to practice sorcery to bring trouble on anybody outside their group who criticised their traditions. ${ }^{69}$ Nevertheless, here in the Netherlands no such physical conflict has been reported. Even though they are different, they are still aware that they are "tunggal sak balung" (come from the same bone) which is their Javanese origin. This has led them to return to their ethical principles of guyub (communality), rukun (harmony), and gotong royong (solidarity).

That is why, according to Denny, to see this phenomenon of Islamic ritual merely as a 'fight' between 'official' and 'popular' Islam is too simplistic. It is true that there are important dimensions to the distinction, and it is important to know which one of the various traditions constitutes the normative practice. But, for him, "it is better to view ritual ideas and practices among Muslims as elements of a

\footnotetext{
${ }^{68}$ Interview on February 11, 2005.

${ }^{69}$ Interview on June 14, 2005.
} 
total symbol and action system than as a set of mutual antagonisms". ${ }^{70}$

According to Mulder, the Kejawen Muslims' maintaining of the heritage of the Agama Djawa could be seen as an endeavour to preserve their identity among other strange cultures. ${ }^{71}$ This, according to Bowie, because people are in possession of any quality or characteristic that gains a person acceptance or admission. They belong to linguistic and ethnic or cultural groups, or may identify themselves with a religious, occupational, or lifestyle community. They will be consciously aware of their particular identity if they come up against other different groups. ${ }^{72}$ In this regard, symbols can be influential and bring about particular meanings when they are supported by political, economic and social relationships.

\section{Conclusion}

It is absolutely incorrect to conclude that slametan is purely an animistic religious rite by observing at the fact that there are many Islamic elements implanted in it. Nor is it completely Islamic, considering that it is a result of a very long attempt of Islamization in Java. The most appropriate conclusion is that the slametan consists of two major elements: the core and the periphery. The core element of the slametan is the Islamic prayer planted in it initially by Javanese Muslim leaders to replace the Javanese incantations. Meanwhile the periphery elements lie in local Javanese symbols preserved by those some Muslim leaders in order to propagate Islam gradually without any abrupt shocks.

The discussion of slametan is not new among the Javanese. It is still one of main topics of discussion among the Javanese Surinamese Muslims in the Netherlands, although it is not as intense as in their country of origin. Like the question of qiblat, the slametan has become

${ }^{70}$ Frederick M. Denny, "Islamic Ritual: Perspectives and Theories", in Richard C. Martin (Ed.), Approaches to Islam in Religious Studies, (Tucson: The University of Arizona Press, 1985), p. 77.

${ }^{71}$ Niels Mulder, Agama, Hidup Sehari-hari, dan Perubahan Budaya: Jawa, Muangthai dan Filipina, Penerjemah: Satrio Widiatmoko, (Jakarta: PT Gramedia Pustaka Utama, 1999), p. 242-243.

${ }^{72}$ Fiona Bowie, The Anthropology of Religion: an Introduction, (UK: Blackwell Publishing Ltd, 2000), p. 72. 
problematic for them since it is related mainly to the issue of identity. Since the Kejawen Muslims are aware that, being descendants of Javanese people, they already possessed their own religious as well as cultural identity inherited from their ancestors. Their Javanese identity, then, is the most important thing to them and has to be preserved. Therefore, they have consistently maintained their identity by attempting to perform all the Javanese rituals including the slametan.

On the other hand, the moderate-reformist and reformist Muslims are convinced that being Muslim is much more important than being Javanese. To be a good Muslim one has to believe only in Allah, not in other spirits and invisible beings, and it has nothing to do with Arabic or Javanese identity. Here, the reformists take a contradictory position to that of the other two groups by completely rejecting performing the slametan. The moderate-reformists assume a milder one; they do perform the slametan, but they totally exclude the offering sajen and burning incense.

This study shows that the performing of the slametan among the Surinamese Javanese Muslims in the Netherlands has undergone less change than might have been expected. Some changes have taken place in relation to a few accoutrements such as the melati blossom and the banana leaves and these have been inevitable for geographical reasons, and have to be considered as not essential since the Kejawen Muslims' enthusiasm for performing the ritual is more than obvious. The overwhelming intention to preserve the slametan is also bolstered by the resistance and criticism from both the other moderate-reformist and reformist groups.

However, the real change that should be taken into account is the change of religious-cultural orientation among the Surinamese Javanese Muslims, which according to some informants has also happened. Some members of the Kejawen Muslim group have abandon their membership and followed another group. Consequently, they no longer participate in the slametan held by their erstwhile group and concentrate on their new religious-cultural identity, either as moderatereformist or reformist Muslims. As a result of the migration process, this religious-cultural change can be explained by what Van Koningsveld calls 'the partial transplantation of their cultural-religious 
heritage' and 'the partial blending of religious variants caused by intergroup contacts'. ${ }^{73}$ Among the former, the abandoning of slametan has led to cultural impoverishment but at the same time to 'purification' from local pre-Islamic elements as revealed in the reformist group. While among the latter, the modification or complete abandoning of slametan is a behavioural deviation as a result of inter-group interactions. ${ }^{74}$ The moderate character of Al-Jami'atul Hasanah has resulted from its close interaction with PPME is a clear example of this premise.

${ }^{73}$ W.A.R. Shadid and P.S. van Koningsveld, The Integration of Islam and Hinduism in Western Europe, (Kampen: Kok Pharos Publishing House, 1991), pp. 230-231.

${ }^{74}$ Here, Van Koningsveld's account that this change may cause schismatic development among the Surinamese Javanese Muslims is also proved from my interviews. However, he made a small but significant mistake in his example about qiblat. The change of the direction of prayer was adopted by some of them from the West to the East, not vice versa. Consequently, some of them have not changed their qiblat since they want to follow their forefathers in Java who face to the West, not to the East. Ibid., p. 231. 


\section{Bibliography}

Beatty, Andrew, "Adam and Eve and Vishnu: Syncretism in the Javanese

Slametan," in The Journal of the Royal Anthropological Institute, vol. 2, No. 2. June 1996.

Bowie, Fiona, The Anthropology of Religion: an Introduction (UK: Blackwell Publishing Ltd, 2000).

Denny, Frederick M., "Islamic Ritual: Perspectives and Theories", in Richard C. Martin (Ed.), Approaches to Islam in Religious Studies (Tucson: The University of Arizona Press, 1985).

Dessing, Nathal M., Rituals of Birth, Circumcision, Marriage, and Death among Muslims in the Netherlands (The Hague: Peeters, 2001).

Fananie, Zainuddin and Atiqa Sabardila, Sumber Konflik Masyarakat Muslim Mubammadiyab-NU Perspektif Keberterimaan Tablil (Surakarta: Muhammadiyah University Press, 2000).

Federspiel, Howard M., A Dictionary of Indonesian Islam (Ohio: Center for International Studies Ohio University, 1995).

Geertz, Clifford, The Religion of Java (London: The Free Press of Glencoe, 1960).

Helmy, Masdar, Islam and Javanese Acculturation: Textual and Contextual Analysis of the Slametan Ritual, MA Thesis Islamic Studies (Montreal: Mc Gill University, 1999).

Ichwan, M. Nur, "Continuing Discourse on Keblat: Diasporic Experiences of the Surinamese Javanese Muslims in the Netherlands", in Sharqiyyat 11 (1999).

Koentjaraningrat, Javanese Culture (New York: Oxford University Press, 1985).

Mulder, Niels, Agama, Hidup Sehari-hari, dan Perubahan Budaya: Jawa, Muangthai dan Filipina, terj. Satrio Widiatmoko (Jakarta: PT Gramedia Pustaka Utama, 1999).

Nasution, Harun, (Ed.), Ensiklopedi Islam Indonesia IAIN Syarif Hidayatullah Jakarta (Jakarta: Djambatan, 1992). 
Peacock, James L., Purifying the Faith: The Mubammadijah Movement in Indonesian Islam (Arizona: Arizona State University, 1978).

Schimmel, Annemarie, Mystical Dimension of Islam (Chapel Hill: The University pf North Carolina Press, 1975).

Shadid, W.A.R. and P.S. van Koningsveld, The Integration of Islam and Hinduism in Western Europe (Kampen: Kok Pharos Publishing House, 1991).

Suparlan, Parsudi, The Javanese in Surinam: Ethnicity in an Ethnically Plural Society, Ph.D. thesis submitted to University of Illinois (Urbana: University of Illinois, 1976).

Van Arendock, C., "Salam", in The Shorter Encycloopaedia of Islam, ed. H. A. R. Gibb and J. Kraners (Leiden: E. J. Brill, 1953).

Van Wengen, G. D., The Cultural Inheritance of the Javanese in Surinam (Leiden: E. J. Brill, 1975).

Woodward, Mark R., Islam in Java: Normative Piety and Mysticism in the Sultanate of Yogyakarta (Tucson: The University of Arizona Press, 1989). 